\title{
SCOPE OF THE APPLICATION OF INTERNATIONAL HUMANITARIAN LAW (IHL) IN SITUATIONS OF NON- INTERNATIONAL ARMED CONFLICTS: EXTENDED APPLICABILITY OF COMMON ARTICLE.3
}

\author{
Tahira Yasmeen \\ Visiting Lecturer \\ University Gillani Law College \\ Bahauddin Zakariya University Multan \\ E-mail: tahirafaizmalik@yahoo.com
}

\begin{abstract}
The applicability of International Humanitarian Law (IHL) in non-international conflicts is a complex phenomenon due to the undefined and unannounced nature of non-international armed conflicts. International Humanitarian Law extends its applicability to the armed conflicts of non-international nature between state and non-state armed groups or between non-state armed groups. Common article.3 to the Geneva Conventions of 1949, and 1977 Additional Protocol II to the Geneva Conventions, provide criteria for the applicability of IHL However, the states are often seen reluctant to accept international legal oversight into their internal matters and this phenomenon of violence often need to be identified and defined. This paper investigates the scope of the application of International Humanitarian Law in situations of Non-International Armed Conflicts, mainly focussing on the extended applicability of Common Article. 3 to the Geneva Conventions 1949, in situation of non-international armed conflicts. Various types and nature of armed conflicts, the applicability of International Humanitarian Law to non-international conflicts are discussed with special reference to the scope and applicability of Common Article.3 to the Geneva Conventions of 1949. Moreover, the binding force and territorial scope of common article. 3 are discussed in a broader context as to assess the applicability of International Humanitarian Law on the changing nature of the non-international armed conflicts.
\end{abstract}

Keywords: International Humanitarian Law, Non-International Armed Conflicts, Common Article.3

\section{INTRODUCTION}

International Humanitarian Law, generally defined as a set of rules that protects people in times of armed conflicts, who are not taking part in hostilities. The reason for this protection is to limit the effects of armed conflicts and put restrict the means and methods of warfare. International Humanitarian Law is also called 'The Law of War'. It also protects the objects such as hospitals, ambulances and significant pieces of cultural property including places of worship, works of art and historical monuments and saves them from the effects of hostilities. International Humanitarian Law prohibits the parties to a conflict from destructing civilian properties and infrastructure. It limits the use of weapons, especially the weapons of mass destructions and prohibits the parties to target civilians (ICRC, 2004).

International Humanitarian Law has mainly emerged and developed through the cooperation and willingness of the states (Stewart, 2003). There are two main treaty sources of International Humanitarian Law, The Hague Conventions (1970) and the four Geneva Conventions. The Hague Conventions (The Hague Law) restrict the methods and means of warfare employed by belligerents against each other. This area of IHL is related to the law of armed conflicts and was mainly developed by The Hague Conventions. 
The Geneva Conventions (The Geneva Law) protects persons who are not, or no longer, participating in the hostilities. These persons mainly include civilians, prisoners of war, the sick and wounded. This area of IHL is concerned with the protection of victims of armed conflicts and was primarily regulated by the four 1949 Geneva Convention. The Hague Conventions restrict the parties to a conflict to use unlimited means and methods of warfare, and the Geneva Conventions provide protection to vulnerable people (Haider, 2013).

International Humanitarian Law applies in times of armed conflicts. The state parties to the 1949 Geneva Conventions have given the International Committee of Red Cross (ICRC) mandate to work for the understanding and circulation of knowledge of International Humanitarian Law and its applicability of in the armed conflicts (IRCRC, 2006). International Humanitarian Law applies mainly to the conflicts between sovereign states. These conflicts can be direct, where the states are directly involved in the conflict, and indirect, where a sovereign state supports the local movement of some other state by supporting the movement by sending troops in that state (GC, 1949).

Non-international armed conflicts are covered under common article 3 to the Geneva Conventions of 1949 and Article I of the Additional Protocol II. Common Article 3 of the Geneva Conventions applies to non-international armed conflicts that occur in the territory of any of the high contracting parties in which one or more non-governmental armed groups are involved. There are situations where conflicts may occur between governmental armed forces and non-governmental armed groups or between such groups only (Sivakumaran, 2012).

The condition of the territory of the high contracting parties has faded now, due to the universal acceptance and rectification. So, any armed conflict between governmental armed forces and non-governmental armed groups or between such groups is considered as a conflict occurred in the territory of the high contracting parties to the convention. According to these provisions, there are two types of armed conflicts, recognised by International Humanitarian Law, international armed conflicts, and non-international armed conflicts. These provisions can be used as an assumption of the nature of armed conflicts.

Non-international armed conflicts are generally known as the conflicts that take place within the territory of a State in which the armed forces of no other State participate. For example, a protracted armed violence between the armed forces of a state and the rebels and insurgent groups. There are specific provisions of law that deal with the noninternational armed conflicts. Common Article.3 to the Geneva Conventions (1949) generally covers the matter of non-international armed conflicts. Due to the variety of the situations and different natures of these conflicts, different laws are applying in different situations. The customary rules of International Humanitarian Law and Treaty Laws are employed to deal the matters, along with the common article.3, according to the nature of the armed conflicts.

"As defined by Geneva Conventions, the situations of internal disturbances generally convert into a non-international armed conflict when these disturbances reach to a certain level. The occurrence of mere violent acts does not convert an internal disturbance into a non-international armed conflict. The non-international armed conflicts occur within the territory of a single state having the status as a high contracting party or state" (ICRC, 2008).

"The modern law recognises armed conflicts by using two variables, intensity of the violence and the level of organisation of the parties. In the absence of any of the two variables, the situation is considered as a mere disturbance. Such situations where exists a confrontation within the country involving certain seriousness, duration, and acts of violence are mere internal disturbances and not amount to armed conflicts" (Chelimo).

\section{TYPES OF ARMED CONFLICTS}

\section{International Armed Conflicts}

International armed conflicts are conflicts that arise between two or more of the high contracting parties. The International Criminal Tribunal for the former Yugoslavia (ICTY) defines International Armed Conflicts, in Tadic case, as "an armed conflict exists whenever there is a resort to armed force between States" (Douglas, 2011). According to IHL treaties, international armed conflicts and the applicability of Geneva Conventions, are defined under Common Article.2 to the Geneva Conventions of 1949 as:

"In addition to the provisions which shall be implemented in peacetime, the present Convention shall apply to all cases of declared war or of any other armed conflict which may arise between two or more 
of the High Contracting Parties, even if the state of war is not recognized by one of them. The Convention shall also apply to all cases of partial or total occupation of the territory of a High Contracting Party, even if the said occupation meets with no armed resistance". (GC, art. 2)

According to Geneva Conventions of 1949, international armed conflicts are conflicts when one or more States have recourse to armed force against another State, regardless of the reasons or the intensity of this confrontation. Apart from applicability of International Humanitarian Law in the situation of armed conflict, there are specific provisions and rules of IHL that apply in peace situations, in the absence of open hostilities, to prevent the armed conflicts between the states. Moreover, no formal declaration of war or recognition of the situation is required. The existence of an international armed conflict, and therefore, the possibility to apply International Humanitarian Law to this situation, depends on what happens on the ground. It is based on factual conditions (Dinstein, 2015). For example, there may be an international armed conflict, even though one of the belligerents does not recognise the government of the adverse party (Fleck, 2013).

The Commentary of the Geneva Conventions of 1949 confirms that "any difference arising between two States and leading to the intervention of armed forces is an armed conflict within the meaning of Article 2, even if one of the Parties denies the existence of a state of war. It makes no difference how long the conflict lasts, or how much slaughter takes place" (Meron, 1987). International Humanitarian also covers the situations of armed conflicts in which peoples are fighting against colonial domination, alien occupation or racist regimes in the exercise of their right to selfdetermination and the wars of civil liberation (AP-I, 1977).

The definition of international armed conflict has been given useful comments by doctrine. International armed conflict, according to D. Schindler: "the existence of an armed conflict within the meaning of Article 2 common to the Geneva Conventions can always be assumed when parts of the armed forces of two States clash with each other. Any kind of use of arms between two States brings the Conventions into effect" (Schindler, 1979). According to H. P. Gasser "any use of armed force by one State against the territory of another, triggers the applicability of the Geneva Conventions between the two States. It is also of no concern whether the party attacked resists.

As soon as the armed forces of one State find themselves with wounded or surrendering members of the armed forces or civilians of another State on their hands, as soon as they detain prisoners or have actual control over a part of the territory of the enemy State, then they must comply with the relevant convention" (Gasser, 1993). The German Joint Services Regulations says that "an international armed conflict exists if one party uses the force of arms against another party. The use of military force by individual persons or groups of persons will not suffice"(ICRC, 2008).

\section{Non-International Armed Conflicts}

According to Geneva Conventions of 1949, Non-international armed conflicts are the armed conflicts waged between the state armed forces and non-state armed groups or between armed groups themselves (ICRC, 2008). Common Article. 3 covers these conflicts, moreover, Additional Protocol II is an instrument that applies, specifically to the noninternational armed conflicts. According to Article.1 of the Additional Protocol II, the protocol covers and deals with all those conflicts which take place in the territory of a High Contracting Party between its armed forces and dissident armed forces or other organized armed groups which, under responsible command, exercise such control over a part of its territory as to enable them to carry out sustained and concerted military operations and to implement this Protocol (AP-II, 1977).

Common article. 3 sets out the acceptable criteria for the existence of non-international armed conflicts based on two elements, the existence of parties to the conflict and the intensity of the violence involved in the conflict (Pejic, 2011). It is very difficult to make a clear distinction between mere disturbances and armed conflicts. The political will of the States plays a major role in making a distinction between mere disturbances and armed conflicts. For ascertaining a situation as armed conflict, two variables are considered critical. The hostilities must reach a certain minimum level of intensity and the situation of armed conflicts, therefore relying heavily on the political will of states to classify the situation as an armed conflict.

\section{LAWS APPLICABLE TO NON-INTERNATIONAL ARMED CONFLICTS}

The states normally refrain from interfering in the internal matters of other states. The states have no authority to interfere in the affairs and conflicts of other states that are recognised by international law as purely domestic and internal. The United Nations also advocates this theory and forbids the interference in the matters which are essentially 
the internal affairs of any State unless there is a threat to peace, a breach of the peace or an act of aggression, in which case the United Nations is entitled to have recourse to enforcement measures (UN Charter, 1945).

Traditionally, non-international armed conflicts have not fallen in the scope of the humanitarian law, but with the passage of time, the states have accepted the interference in the internal matters to avoid the situations of extreme violence and cruelty. To deal the internal situations beyond their control and to save the international community from their effects, the states have allowed rules to be codified governing non-international armed conflicts. The four Geneva Conventions in 1949 were adopted with the inclusion of the provisions that introduced the minimum standards of humanity. These provisions were expected to be observed in situations of the upcoming non-international conflicts. For the purpose of the development of supplementing these standards, Additional Protocol II to the Geneva Conventions (Geneva Protocol II) was adopted in 1977.

The laws that deal with the matters of non-international armed conflicts are considered insufficient due to the expansion of the different kinds of these conflicts with their different types of situations and circumstances. There are two main views that are presented by the legal experts in this regard. According to the first view, it is suggested to reduce the international humanitarian law, to the few provisions of Common Article 3 of the Geneva Conventions, which govern the non-international armed conflicts. They argue that the provisions of common Article 3 are the only legally binding provisions under IHL in the context of non-international armed conflicts.

The second view further creates doubts regarding the sufficiency of the existing legal framework on the matter of noninternational armed conflicts. According to this view, the use of Common Article 3 as a treaty law is very limited that only covers the non-international armed conflicts taking part in the territory of a single state (ICRC, 2008). But these doubts cannot challenge the effectiveness of the laws relating Non-international armed conflicts.

Furthermore, it is also argued and suggested that the changing nature of non-international armed conflicts require the laws applicable to these armed conflicts, especially the 'common article 3 may be given a different geographical reading as a matter of treaty law'. The politics and state interests keep working for the failure of International Humanitarian Law by misclassifying the armed conflicts. It provides them with the opportunity of breaching the human rights. International humanitarian law to play a crucial part, it needs to adapt and continuously evolve to cater for the changing dynamics of conflicts experienced.

\section{Common Article.3}

Despite all the deficiencies in ascertaining the nature of armed conflicts and lack of proper definition of noninternational armed conflicts, it is widely accepted that the conflicts waged between state armed forces and non-state armed groups or between such groups themselves are considered as Non-International Armed Conflicts. These conflicts are covered by common article. 3 to the Geneva Conventions of 1949, Additional Protocol of 1977 and the rules of Customary International Humanitarian Law. The state practices and international judicial bodies and legal literature provide different criteria to be applied for the assessment of these conflicts in different situations. At least two criteria are considered as indispensable to classify a situation of violence as non-international armed conflict. So, all those conflicts are not considered as non-international armed conflicts that do not meet the criteria that distinguish it from internal disturbances or tensions that do not meet this threshold.

The first criteria of the existence of a non-international armed conflict is based on the recognition of parties involved in a conflict. Common Article 3 expressly refers to 'each Party to the conflict thereby implying that a precondition for its application is the existence of at least two parties'. It is normally not difficult to establish the existence of a state party, however, it is very difficult to determine the existence of a a non-state armed group due to the multiple factors involved in case to case approaches. Nevertheless, it is widely recognised that a non-state party to an NIAC means an armed group with a certain level of organisation that would essentially enable it to implement international humanitarian law (Schindler, 1979).

\section{Binding force of Common Article 3}

The parties to a conflict are bound to oblige the rules of International Humanitarian Law during an armed conflict. Common article. 3 as a treaty law not only binds the states by being party to the Geneva Conventions but also binds the non-state parties as well. There are different theories about the logic behind making non-state parties bound to oblige International Humanitarian Law (ICRC, 2016). 
The customary rules of International Law bind non-state armed groups to oblige the rules of International Humanitarian Law based on the territory of the state where they used to fight. Common article. 3 in this regard acts as customary law because all the substantive provisions of Common Article 3 bind all parties to an armed conflict to oblige the rules of International Humanitarian Law beyond any formal classification or geographical reach. In these types of situations, common article. 3 operates as customary law, and it affirmed by International Criminal Tribunal for Rwanda as well.

The principle of effectiveness implies that the state's obligations bind any power having effect in a state territory or they are made responsible for the implementation or transformation of the rules of international law into the domestic national legislation or having direct applicability of such rules of international law that are self-executing. If a state is bound to oblige some rules of International Law, it ultimately puts non-state parties to oblige the same rules because of being on the territory of that state. It was affirmed by the International Court of Justice, as a reminder, in the Nicaragua case that:

"Article 3 which is common to all four Geneva Conventions of 12 August 1949 defines certain rules to be applied in the armed conflicts of a non-international character. There is no doubt that in the event of international armed conflicts these rules also constitute a minimum yardstick, in addition to the most elaborate rules which are also to apply to international conflicts. These are rules which, in the Court's opinion, reflect what the Court in 1949 called 'elementary considerations of humanity." (ICJ, 1986, para. 218)

The Court also reiterated this position and stressed that:

"Because the minimum rules applicable to international and non-international conflicts are identical, there is no need to address the question whether those actions must be looked at in the context of the rules which operate for the one or the other category of conflict. The relevant principles are to be looked for in the provisions of Article 3 of each of the four Conventions of 12 August 1949, the text of which, identical in each Convention, expressly refers to conflicts not having an international character. " (ICJ, 1986, para. 218)

\section{Territorial scope of application of Common Article 3}

The limited scope and application of common article. 3 is often criticised and argued that it applies to the conflicts of non-international nature that arise within the territory of a single state, including armed forces and one or more organised non-state armed groups or between such groups themselves. (Pictet, 1958). The plain language used in common article.3, by itself, provides a defence to this criticism. The different interpretation of the text gives it different meanings and extends its scope and applicability.

The conflicts of non-international character fall under the scope of common article.3 by their organisation and intensity. So, the scope and applicability of common Article.3 extend to the non-international armed conflicts spread over the territory of more than one state. A wide interpretation of the text clarifies that territorial clause has not been included deliberately to lemmatise the territorial or geographical scope of common article.3 in this regard. (ICRC, 1948).

The territorial scope and applicability of International Humanitarian Law are rejected by interpreting and comparing the provisions of Geneva Conventions and Additional Protocol II, related to the occurrence of conflicts in the territory of one state (GC, 1949). According to the Common article.3, refers to non-international armed conflicts occurring in the territory of one of the High Contracting Parties, on the other hand.

\section{CONCLUSION}

The application of International Humanitarian Law in a different context has remained a topic of discussion among scholars. The rules of International Humanitarian Law clearly define the scope and applicability of International Humanitarian Law in different situations. The aim and purpose of International Law have been the protection of civilians and those persons who are not taking part in hostilities. It prohibits the parties from using unlimited force and targeting the civilian and civilian objects. International Humanitarian Law applies to both the International and no international armed conflicts. Despite, the availability of refugee laws and rules relating displaced persons, the common article 3 of the Geneva Conventions, Additional Protocol II and the customary rules of International Humanitarian Law cover the matter non-international armed conflicts by protecting the displaced persons under the category of civilians. 
Normally states keep their armed conflicts unannounced and try to deal with the conflicts internally. Common article. 3 defines the non-international armed conflicts as the armed conflicts waged between the state armed forces and nonstate armed groups or between armed groups themselves. Common article. 3 sets out the acceptable criteria for the existence of non-international armed conflicts based on two elements, the existence of parties to the conflict and the intensity of the violence involved in the conflict. There are specific provisions of law that deal with the noninternational armed conflicts. Common Article.3 to the Geneva Conventions (1949) generally covers the matter of non-international armed conflicts.

\section{REFERENCES:}

Chelimo, GC (2011). 'Defining Armed Conflict in International Humanitarian Law' Inquiries Journal of Social Science and Humanities <http://www.inquiriesjournal.com/articles/508/defining-armed-conflict-in-internationalhumanitarian-law> accessed 10 August 2020

Dinstein, Y. (2015). The conduct of hostilities under the law of international armed conflict (Cambridge University Press)

Douglas, G. (2011). 'The Mavi Marmara incident and blockade in armed conflict' 81 BYIL 171

Fleck, D. (2013). The Handbook of Humanitarian Law in Armed Conflicts (3rd edn, Oxford University Press)

Geneva Convention I, 1949

Geneva Convention II, 1949

Geneva Convention III, 1949

Geneva Convention IV, 1949

Haider, H. (2013). International Legal Frameworks for Humanitarian Action: Topic Guide (GSDRC, University of Birmingham)

ICRC. (2004). 'What is Humanitarian Law? $<$ https://www.icrc.org/eng/assets/files/other/what_is_ihl.pdf $>$ accessed 10 August 2016

ICRC. (2016). 'State Parties to the Main Treaties of IHL'<https://ihl-databases.icrc.org/ihl> accessed 10 August 2019.

International Committee of the Red Cross (ICRC). (2008). "How is the Term "Armed Conflict" Defined in International Humanitarian Law?' <https:/www.icrc.org/eng/resources/documents/article/other/armed-conflictarticle-170308.htm $>$ accessed 12 April 2016.

International Court of Justice (ICJ), Case concerning Military and Paramilitary Activities in and against Nicaragua (Nicaragua v. United States of America), 27 June 1986, Judgment, para. 218.

Meron, T. (1987). 'The Geneva conventions as customary law' 81 AJIL 348.

Pejic, J. (2011) 'The protective scope of Common Article 3: more than meets the eye, 93 IRRC 189

Pictet, JS. (1958). Commentary to the Fourth Geneva Convention relative to the Protection of Civilian Persons in Time of War (ICRC, Geneva)

Protocol Additional to the Geneva Conventions 1949, and relating to the Protection of Victims of Non-International Armed Conflicts (Protocol II), 1977

Schindler, D. (1979). 'The different Types of Armed Conflicts According to the Geneva Conventions and Protocols' 163 RCADI 131

Sivakumaran, S. (2012). The Law of Non-International Armed Conflict (Oxford University Press)

Statutes of the International Red Cross and Red Crescent Movement, 2006 
Stewart JG. (2003). 'Towards a Single Definition of Armed Conflict in International Humanitarian Law' 850 IRRC 313

United Nations, Charter of the United Nations (24 October 1945) 1 UNTS XVI

XVII International Conference of the Red Cross in Stockholm, 1948 